\author{
Adam TOKARSKI ${ }^{1}$ \\ Damian KORDOS ${ }^{2}$
}

\title{
PROJEKT APLIKACJI MOBILNEJ DLA LOTNICTWA OGÓLNEGO
}

\begin{abstract}
Niniejszy artykuł przedstawia możliwości zastosowania aplikacji mobilnych dla urządzeń przenośnych w lotnictwie ogólnym (General Aviation). Pierwsza część publikacji stanowi ogólne przybliżenie tematu urządzeń typu PED (Portable Electronic Device) wykorzystywanych na pokładach współczesnych samolotów. Część druga dotyczy prezentacji własnego projektu realizowanego $w$ ramach inżynierskiej pracy dyplomowej jednego z autorów. Projekt ten zakłada stworzenie aplikacji wspomagającej pilota podczas wykonywania lotów VFR (Visual Flight Rules) według przepisów z widocznością ziemi. Do głównych jej funkcji należy detekcja fazy lotu, zapis wybranych parametrów oraz automatyzacja niektórych czynności w oparciu o interakcję użytkownika i dane pochodzące z sensorów urządzenia. Przybliżona zostanie charakterystyka problematyki, przyjęte założenia oraz osiągnięte rezultaty. Trzecia część zawiera analizę wyników badań przeprowadzonych w warunkach rzeczywistego lotu na samolocie Socata TB-9 Tampico, będącego własnością Ośrodka Kształcenia Lotniczego Politechniki Rzeszowskiej. Wykonane próby obejmowały rejestrację podstawowych parametrów lotu, tj. pozycji geograficznej, wysokości, prędkości, szacowanej dokładności pomiaru, itp. Uzyskany materiał stanowił podstawę do udoskonalenia algorytmów, kalibracji oraz wyznaczenia wymaganych współczynników. Dodatkowo przebieg każdego lotu zobrazowany został w programie Google Earth poprzez wyznaczenie trójwymiarowej trajektorii. Badania wykorzystane mogą zostać do określenia funkcjonalności urządzeń przenośnych oraz stanowić inspirację dla dalszych kierunków rozwoju.
\end{abstract}

Słowa kluczowe: aplikacje mobilne, EFB, lotnictwo ogólne

\section{Wprowadzenie}

Dynamiczny rozwój lotnictwa cywilnego w okresie powojennym niósł ze sobą nowe perspektywy w obszarach bezpieczeństwa i powszechności podniebnych podróży. Implikacją postępu technologicznego stały się coraz bardziej zaawansowane statki powietrzne, wyposażone w najnowsze rozwiązania konstrukcyjne.

\footnotetext{
${ }^{1}$ Adam Tokarski, email: tokarski@ poczta.pl

2 Autor do korespondencji/corresponding author: Damian Kordos, Politechnika Rzeszowska, al. Powstańców Warszawy 8, 35-959 Rzeszów, email: d_kordos@prz.edu.pl
} 
Rozwój ten spowodował jednak powstanie nie tylko nowych możliwości, ale również zagrożeń. Bezpieczna eksploatacja statków powietrznych zaczęła wymagać wszechstronnego przygotowania pod kątem operacyjnym. Pomimo powstawania wyspecjalizowanych jednostek zajmujących się wyłącznie planowaniem lotu, do dnia dzisiejszego kluczową rolę odgrywa postać dowódcy, który bezpośrednio odpowiedzialny jest za bezpieczeństwo osób i mienia na pokładzie.

Wzrastająca złożoność operacji wymagała rozbudowy zasobów dokumentacji pokładowej. Dokumenty zaczęły być noszone w podręcznych torbach, których masa przekraczać mogła nawet $25 \mathrm{~kg}$ [1]. Powodowało to niepotrzebne obciążenie fizyczne oraz utrudnienia w organizacji pracy. Czasochłonność i wysokie koszty procesu aktualizacji dodatkowo nasilały logistyczne wyzwania stojące przed działami operacyjnymi.

W związku z miniaturyzacją elektroniki, na początku XXI wieku nastąpiła gwałtowna popularyzacja urządzeń przenośnych, otwierając nowe perspektywy dla poprawy ergonomii pracy w kokpicie. Linie lotnicze zaczęły dostrzegać korzyści płynące $\mathrm{z}$ redukcji papierowej dokumentacji na rzecz odpowiedników $\mathrm{w}$ formie cyfrowej. W nawiązaniu do tradycyjnej torby zabieranej przez pilotów na pokład, urządzenia te otrzymały nazwę ,elektronicznych toreb” EFB (Electronic Flight Bag). Szacuje się, iż obecnie (szacunek na rok 2016) mniej niż 5\% przewoźników na świecie korzysta z urządzeń zapewniających elektronicznie przechowywaną dokumentację o znaczeniu kluczowym we wszystkich fazach lotu [2]. Wiąże się to z silnym przywiązaniem przemysłu lotniczego do tradycyjnych rozwiązań. Technologiczne innowacje, np. tzw. tablety, sukcesywnie przełamują tę barierę, proponując coraz doskonalsze rozwiązania znajdujące zastosowanie we wszystkich rodzajach współczesnego lotnictwa [5-9].

\section{Urządzenia typu EFB}

Urządzenia typu EFB podzielone zostały na trzy kategorie sprzętowe i systemowe (Rys. 1) [2]. Podział sprzętowy uwzględnia klasę 1 (urządzenia całkowicie przenośne), klasę 3 (pełna integracja $\mathrm{z}$ awioniką pokładową za pośrednictwem standardu ARINC) oraz klasę 2, będącą syntezą klas 1 i 3. Wszystkie trzy klasy obsługują oprogramowanie typu A i B, niemniej jedynie klasa 3 wykorzystuje system typu C, mający zastosowanie w krytycznych fazach lotu.

W Stanach Zjednoczonych wymagane jest spełnienie technicznych standardów TSO (Technical Standard Orders), będących częścią certyfikacji według przepisów FAR (Federal Aviation Requirements). Komercyjne zastosowanie urządzeń EFB szczegółowo opisuje biuletyn Advisory Circular AC 120-76B. Wykorzystanie urządzeń przenośnych $\mathrm{w}$ lotnictwie niekomercyjnym określa przepis Part 91, który dotyczy samolotów tłokowych i turbośmigłowych o maksymalnej masie 12500 funtów, natomiast samoloty wielosilnikowe uwzględ- 
nione zostały w przepisach Part 91F i AC 120-76C. Przepisy Part $91 \mathrm{w}$ zamian za proces certyfikacyjny dopuszczają samodzielną ocenę pilota-dowódcy dotyczącą ewentualnego negatywnego wpływu urządzenia na inne systemy pokładowe. Dopuszczone jest również stosowanie urządzeń EFB w zamian za dokumentację papierową, spełniając podstawowe wymagania aktualności oprogramowania i danych [3]. W Europie za zapewnienie regulacji prawnych odpowiedzialna jest EASA.

Rys. 1. Klasyfikacja urządzeń typu EFB

Fig. 1. Classification of EFB-type instruments

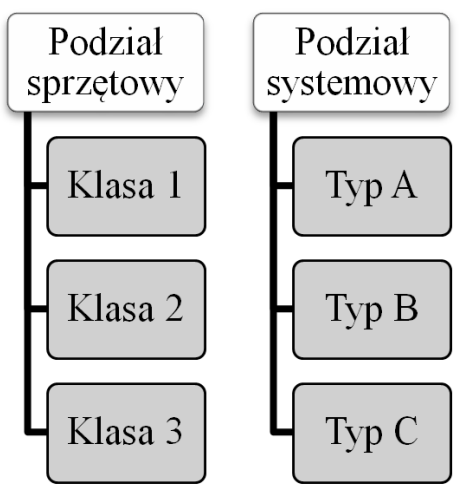

Dotychczas odnotowanych zostało kilka incydentów i wypadków lotniczych bezpośrednio powiązanych z wykorzystaniem urządzeń EFB. Przykładem incydentu jest przypadek samolotu Airbus A320-500 linii Emirates, który wykonywał rozbieg przy zredukowanym ciągu startowym. Ze względu na zbyt duże zmniejszenie jego wartości spowodowane błędnymi obliczeniami załogi, próba rotacji zakończyła się uderzeniem części ogonowej w pas startowy. W raporcie końcowym australijskie biuro ATSB wydało zalecenie dla załóg latających podkreślając konieczność samodzielnej ewaluacji wyników obliczeń uzyskanych za pośrednictwem urządzeń typu EFB [2].

\section{Urządzenia przenośne}

Idea elektronicznych kalkulatorów lotu powstała na bazie wykorzystania przez pilotów samolotów lekkich pierwszych laptopów wyposażonych w podstawowe oprogramowanie służące do obliczeń osiągowych [1]. Odgrywając rolę prekursora, koncepcja EFB znalazła kontynuację w wyniku ewolucji telefonii komórkowej, nawigacji satelitarnej i digitalizacji społeczeństwa.

Warto jednak zwrócić uwagę na dwojaki nurt rozwoju, nakreślony przez samą klasyfikację. $\mathrm{Z}$ jednej strony przemysł lotniczy wdraża systemy stanowiące integralne wyposażenie awioniki pokładowej (EFB klasa 3 typ 3) podlegające 
certyfikacji przez władzę lotniczą. Z drugiej zaś strony tworzone są aplikacje na urządzenia niespełniające podstawowych wymogów (np. tzw. smartfony, iPady, Tablety, itp.). Co zatem przyczyniło się do komercyjnego sukcesu tego rodzaju oprogramowania? Odpowiedzią na to pytanie są możliwości sprzętowe. Okazuje się, iż urządzenia stosowane obecnie na co dzień posiadają kilkukrotnie większą moc obliczeniową niż komputery stacjonarne sprzed niespełna kilku lat. Pojawiła się zatem perspektywa tworzenia zaawansowanych programów wykorzystując już istniejące zasoby sprzętowe. Co więcej, istnieje możliwość ich rozbudowy poprzez stosowanie sygnałów zewnętrznych, takich jak ADS-B (np. GDL 39), odbiornik GPS (np. GLO Portable GPS) oraz dwustronną wymianę danych pomiędzy urządzeniem i awioniką pokładową. Funkcja ta szczególnie będzie doceniona przez użytków m.in. Garmin GNS 430W np. podczas tworzenia planu lotu, gdy w zamian za długotrwałe wprowadzanie punktów trasowych jesteśmy w stanie przygotować plan na tablecie, przesyłając go w czasie rzeczywistym do urządzenia pokładowego.

Aplikacja mobilna to termin ogólny, odnoszący się do oprogramowania działającego na urządzeniach przenośnych. Podstawową klasyfikację rynku aplikacji dla potrzeb lotnictwa stanowi podział na ofertę komercyjną i niekomercyjną. Pierwsza grupa łączy zazwyczaj dobrze rozpoznawalne marki o silnej pozycji w branży oraz jednostki wyspecjalizowane w technologiach mobilnych. Do drugiej grupy należą przeważnie firmy spoza przemysłu oraz indywidualni deweloperzy promujących własne rozwiązania. Istotną różnicą pomiędzy obiema grupami jest zaplecze operacyjne producenta. Płatne aplikacje zapewniają aktualność danych nawigacyjnych w regularnych cyklach AIRAC, co ma zasadniczy wpływ na możliwość wykorzystania operacyjnego.

Wybór właściwego oprogramowania powinien zostać dokonany na podstawie kilku kryteriów. Najważniejszym jest system operacyjny urządzenia. Posiadaczy iPada-ów firmy Apple interesują aplikacje działające w systemie iOS, takie jak Garmin Pilot, ForeFlight, czy Jeppesen FliteDeck. Użytkownicy znacznej większości tabletów i smartfonów korzystają ze środowiska Android, gdzie ciekawym przykładem jest aplikacja SkyDemon. Platforma Windows nie jest obecnie w zasięgu zainteresowania znaczących producentów. Równie ważnym czynnikiem jest rodzaj i częstotliwość wykonywanych operacji. Dla przykładu, firma Jeppesen oferuje osobne aplikacje dla lotów VFR i IFR, odpowiednio Jeppesen FliteDeck VFR i FliteDeck. Jeżeli należymy do grona pilotów prywatnych, warto jest znaleźć ofertę zapewniającą aktualne dane nawigacyjne adekwatne do naszych potrzeb. Na rysunku 2 przedstawiony został zbiór niektórych funkcji będących na wyposażeniu aplikacji lotniczych. 


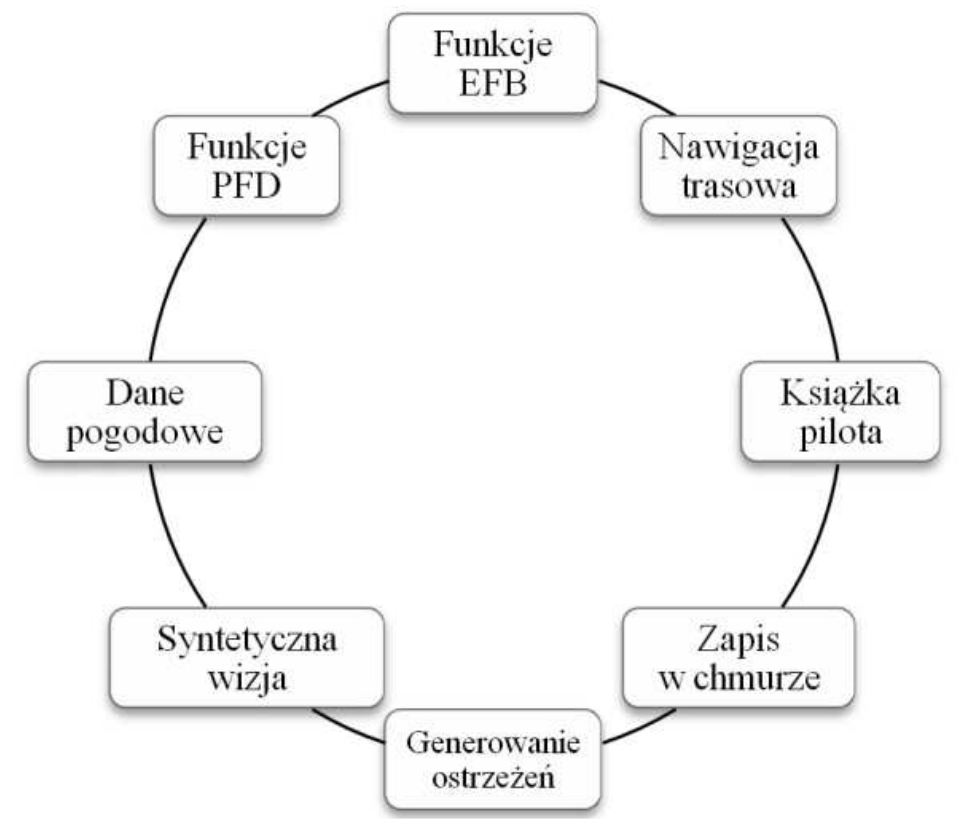

Rys. 2. Zestawienie istotnych funkcji oferowanych przez aplikacje komercyjne

Fig. 2. The essential functions offered by commercial applications

\section{Projekt aplikacji mobilnej}

Pomysł stworzenia własnej aplikacji wspomagającej loty treningowe na samolotach klasy GA (General Aviation) powstał na bazie wniosków jednego z autorów niniejszego artykułu dotyczących przebiegu procesu szkolenia lotniczego w Ośrodku Kształcenia Lotniczego Politechniki Rzeszowskiej. Analizie poddane zostały kluczowe błędy popełniane przez studentów-pilotów będących w początkowej fazie szkolenia podczas samodzielnych lotów nawigacyjnych. Zauważono, iż uczniowie napotykają typowe problemy związane z percepcją, czynnościami proceduralnymi oraz sztuką pilotażu. W dalszej części artykułu wskazane zostaną aspekty, na które w projekcie zwrócono szczególną uwagę.

Pierwsze założenie projektowe dotyczy regulacji prawnych. Na obszarze Unii Europejskiej niezarobkowe operacje lotnicze, wykonywane na statkach innych niż skomplikowane statki powietrzne, podlegają przepisom PART-NCO [4]. Nakłada to następujące ograniczenia projektowe:

- aplikacja nie jest źródłem nawigacyjnym w trakcie lotu,

- urządzenie nie jest montowane na stałe w kokpicie,

- nie stanowi podstawowego wyposażenia łączności radiowej,

- nie wpływa na zdatność statku powietrznego do lotu, nawet w przypadku nieprawidłowego działania, 
- urządzenie znajduje się w łatwo dostępnym dla pilota miejscu i może być szybko zdemontowane.

Drugie założenie określa mechanizm działania programu, który oparty został na detekcji aktualnej fazy lotu poprzez wykorzystanie wbudowanych sensorów, tj. przyspieszeniomierzy i odbiornika GPS. Określenie etapu lotu umożliwia sterowanie aplikacją w zależności od bieżących potrzeb. Do wyszczególnionych faz lotu należą:

- GND - faza na ziemi, silnik wyłączony (Ground)

- STP - faza uruchomionego silnika (Start-Up)

- TAX - faza kołowania (Taxi)

- ENR - faza przelotu (En-Route)

- APP - faza podejścia (Approach)

- LDG - faza na ziemi, kołowanie po lądowaniu (Landing)

- SDN - faza na ziemi po wyłączeniu silnika (Shut-Down)

Na rysunku 3 przedstawiony został ogólny schemat funkcji określonych na etapie projektowym.

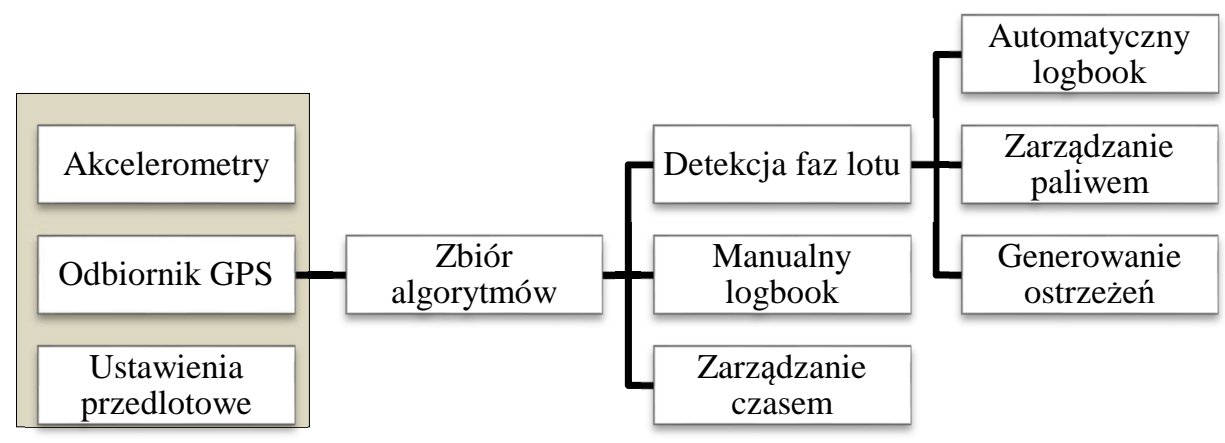

Rys. 3. Schemat przedstawiający najważniejsze funkcje programu

Fig. 3. Block diagram representing the most important functions of program

Trzecim założeniem jest miejsce zamontowania urządzenia w kabinie. Zgodnie z NCO.IDE.A.100 urządzenie nie może być montowane na stałe oraz ma znajdować się w łatwo dostępnym dla pilota miejscu, umożliwiając szybki demontaż [4]. Koncepcja projektu nakłada dodatkowe wymaganie w postaci możliwości pomiaru przyspieszeń liniowych pochodzących od struktury płatowca celem rejestracji drgań, których źródłem jest zespół napędowy. Ostatecznie wybraną lokalizacją została wewnętrzna powierzchnia wolantu, ograniczając zastosowanie do samolotów wyposażonych w ten rodzaj sterów.

Wykrycie poszczególnych etapów lotu zapewniają rozbudowane algorytmy obliczeniowe. W przypadku detekcji pracy silnika, rozpatrywany jest przebieg wartości sumy bezwzględnych przyspieszeń liniowych $\mathrm{a}_{\mathrm{xyz}}(\mathrm{t})$ na poszczególnych osiach układu w funkcji czasu. Ma to na celu eliminację błędu powodowanego 
składową przyspieszenia ziemskiego $\left(\mathrm{g}=9,81 \mathrm{~m} / \mathrm{s}^{2}\right)$. Sygnał poddawany jest dalszym przekształceniom, ostatecznie umożliwiając wykrycie chwili uruchomienia zespołu napędowego (Rys. 4). Zapisywany jest czas, a układ odpowiedzialny za monitorowanie zużycia paliwa rozpoczyna pracę. Wartość wydatku przyjęta $\mathrm{w}$ obliczeniach podlega korekcji wraz $\mathrm{z}$ postępującym lotem, aby wskazania możliwie dokładnie estymowały przepływ rzeczywisty. Ciekawą funkcją jest głosowe i wizualne powiadomienie o przekroczeniu długości lotu na danym zbiorniku wraz z liczbową reprezentacją aktualnej różnicy ilości paliwa pomiędzy zbiornikami, wyrażoną w jednostce objętości i masy. Jest to zabezpieczenie przed błędem popełnianym przez początkujących pilotów, którzy nagminnie zapominają o przełączeniu zaworu zbiornika paliwa podczas lotów trasowych.

Wykrycie kolejnych faz realizowane jest poprzez monitorowanie zmiany położenia urządzenia w czasie na podstawie sygnału GPS. Gdy przekroczony zostanie ustalony próg czułości, odpowiedni algorytm sprawdza, czy zmiana prędkości spowodowana była rozpoczęciem np. kołowania, czy jednie chwilowymi zakłóceniami. Wykorzystując osiągi samolotu (np. znaną prędkość rotacji $\mathrm{V}_{\mathrm{R}}$ ), detekcja fazy kołowania i startu nie sprawia większych trudności. Problem pojawia się w momencie rozważań dotyczących lądowania, gdyż loty szkolne charakteryzuje różnorodność manewrów, m.in. ćwiczenia w strefie, serie konwojerów, itd. Kwestię tę rozwiązuje algorytm podejmujący decyzję, czy wykrycie fazy podejścia (na podstawie zmian prędkości, wysokości i odległości od najbliżej położonego lądowiska)było wynikiem pełnego lądowania, tzw. konwojera, lotu poziomego z minimalną prędkością, innego manewru, czy też błędu pomiarowego.

Detekcja faz lotu służy także automatycznej rejestracji czasów, np. uruchomienia silnika, kołowania, startu, lądowania, ale również wykonanych konwojerów wraz z podaniem ich liczby oraz kodu ICAO lotniska (Rys. 5). Funkcja ta eliminuje problemy podczas wypełniania dokumentacji przez uczniów, którzy często obciążeni samodzielnym lotem zapominają o uzupełnianiu operacyjnych planów lotu. Niezależnie od zapisu automatycznego, użytkownik posiada również możliwość ręcznego wprowadzania danych poprzez naciśnięcie przycisku raportującego rozpoczęcie operacji. Dzięki temu istnieje możliwość późniejszego sprawdzenia, czy wartości uzyskane automatycznie były poprawne. Oprócz podstawowych danych, takich jak nazwisko dowódcy, datę lotu, znaki rejestracyjne i typ statku powietrznego, w poszczególnych polach zapisane zostały czasy lotów zarejestrowane automatycznie (kolor biały i zielony) oraz manualnie przez pilota (cyjan). Warto zauważyć, iż na trasie trwającej 3,5 h różnica pomiędzy całkowitymi czasami w obu przypadkach wyniosła niespełna $1 \mathrm{mi}$ nutę. 


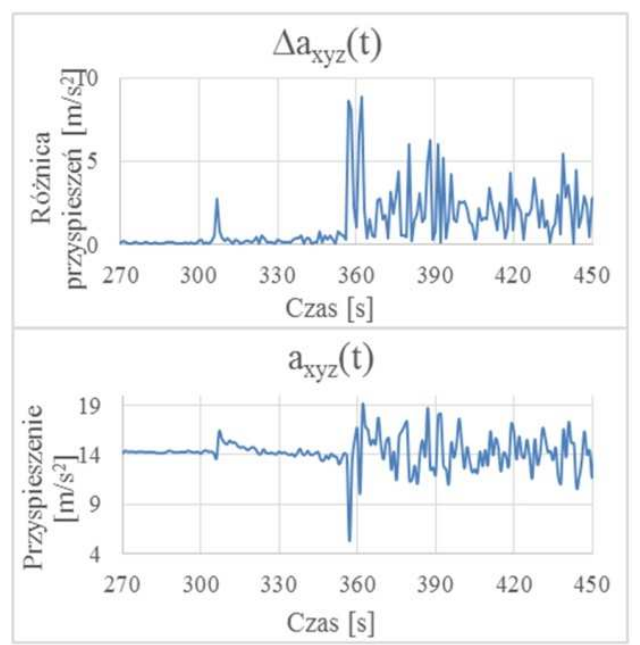

Rys. 4. Wykresy przedstawiające moment wykrycia pracy zespołu napędowego

Fig. 4. Diagrams representing the moment of detection of operation of power unit

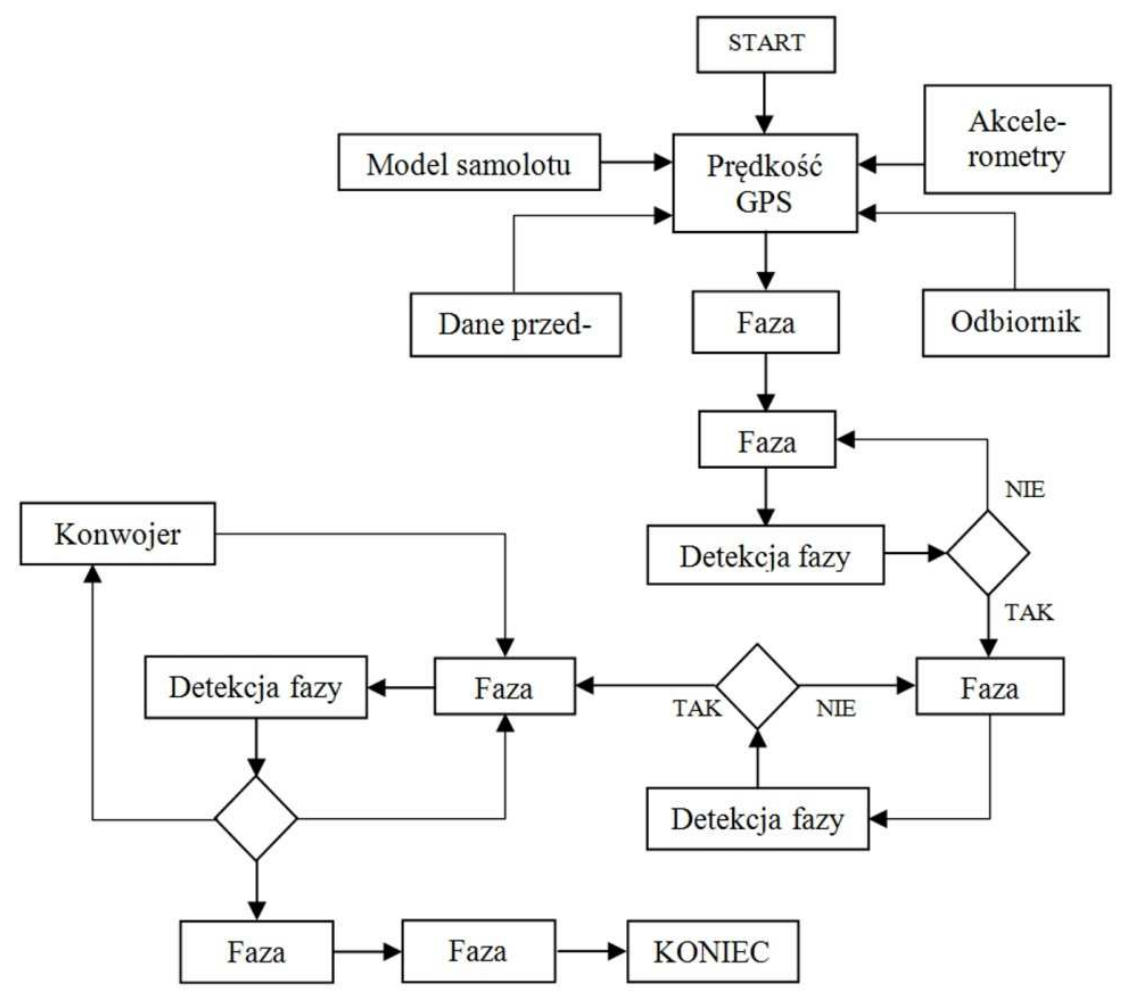

Rys. 5. Ogólny schemat działania układu wykrywania zmiany fazy lotu

Fig. 5. The general block diagram of operation of detection system of flight phase change 
Należy pamiętać, iż zapisane czasy spełniają funkcję wyłącznie informacyjną i nie zastępują papierowej dokumentacji personalnej. Certyfikowany logbook zgodnie z PART-FCL zapewnia natomiast np. aplikacja Garmin Pi$\operatorname{lot}^{\mathrm{TM}}$.

Aplikacja wyposażona została w układ rejestracji dwóch typów danych. Pierwszy stanowią wszelkie czynności wykonane przez pilota w trakcie użytkowania programu. Drugim rodzajem jest rejestrator szybkiego dostępu, zapisujący w pliku CSV (Tab. 1) takie wielkości, jak:

- czas rejestracji w formacie godzina:minuta:sekunda (UTC),

- szacowana dokładność pomiaru,

- szerokość geograficzna,

- długość geograficzna,

- wysokość w metrach,

- prędkość w m/s,

- szacowana ilość paliwa w obu zbiornikach.

Tabela 1. Przykład tabeli zawierającej zapis parametrów lotu w pliku o rozszerzeniu CSV

Table 1. The exemplary table including flight parameters in CSV file

\begin{tabular}{|cccccc|}
\hline TIME [UTC] & ACC [m] & LAT [dd] & LONG [dd] & ALT [m] & SPEED [m/s] \\
$08: 02: 34$ & 3 & 50,10181 & 22,05264 & 236 & 0,54 \\
$08: 02: 43$ & 3 & 50,10172 & 22,05273 & 237 & 1,15 \\
$08: 02: 53$ & 3 & 50,10172 & 22,05290 & 235 & 1,20 \\
$08: 03: 03$ & 3 & 50,10173 & 22,05309 & 234 & 1,35 \\
$08: 03: 14$ & 3 & 50,10177 & 22,05348 & 233 & 2,85 \\
$08: 03: 24$ & 3 & 50,10196 & 22,05361 & 230 & 2,20 \\
$08: 03: 33$ & 3 & 50,10224 & 22,05354 & 231 & 3,23 \\
\hline
\end{tabular}

Edycję pliku zapewnia pakiet Microsoft Office, a dalsze przetworzenie danych możliwe jest np. poprzez program KML Creator. Jest to narzędzie stworzone przez australijskie biuro ds. Badania Wypadków Lotniczych ATSB (Australian Transport Safety Bureau). Wykorzystuje ono arkusz kalkulacyjny, generując plik o rozszerzeniu KLM widoczny m.in. dla programu Google Earth. Możliwe jest wówczas przedstawienie lotu w dwóch wymiarach lub trójwymiarowej trajektorii z użyciem funkcji „Elevation”.

Rysunek 6 przedstawia zobrazowanie przebiegu lotu szkolnego wraz z profilem pionowym. Lot wykonany został na samolocie Socata TB-9 Tampico $\mathrm{w}$ ramach szkolenia zintegrowanego odbywanego przez jednego $\mathrm{z}$ autorów w Ośrodku Kształcenia Lotniczego Politechniki Rzeszowskiej. Trasa obejmowała przelot na wysokości 2000 stóp do lotniska w Masłowie pod Kielcami, wykonanie w celach treningowych tzw. konwojera, następnie powrót do lotniska startu na wysokości 3000 stóp. 
Na podstawie analizy wyników w programie Google Earth (Rys. 6-8) stwierdzono, iż uzyskane rezultaty znacznie przekroczyły oczekiwania z etapu projektowego. Uzyskana dokładność pozioma lokalizacji podczas wszystkich prób mieściła się w przedziale 3-5 m, a oscylacje wysokości nie przekraczały +/- 300 stóp. Pomiary dokonywane były w interwałach 30 sekund, co miało wpływ na deformację płaszczyzny toru lotu. Pojawiła się także możliwość ewaluacji błędów poprzez określenie np. bocznych linowych odchyleń na poszczególnych odcinkach trasowych (Rys. 8).

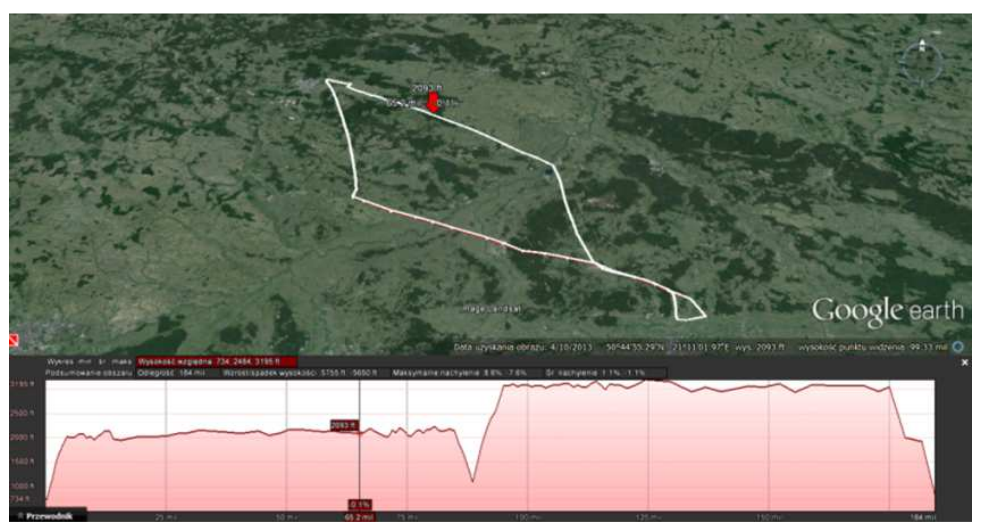

Rys. 6. Zobrazowanie lotu szkolno-treningowego na samolocie Socata TB-9 Tampico

Fig. 6. Visualisation of flight of pilot-training Socata TB-9 Tampico aircraft

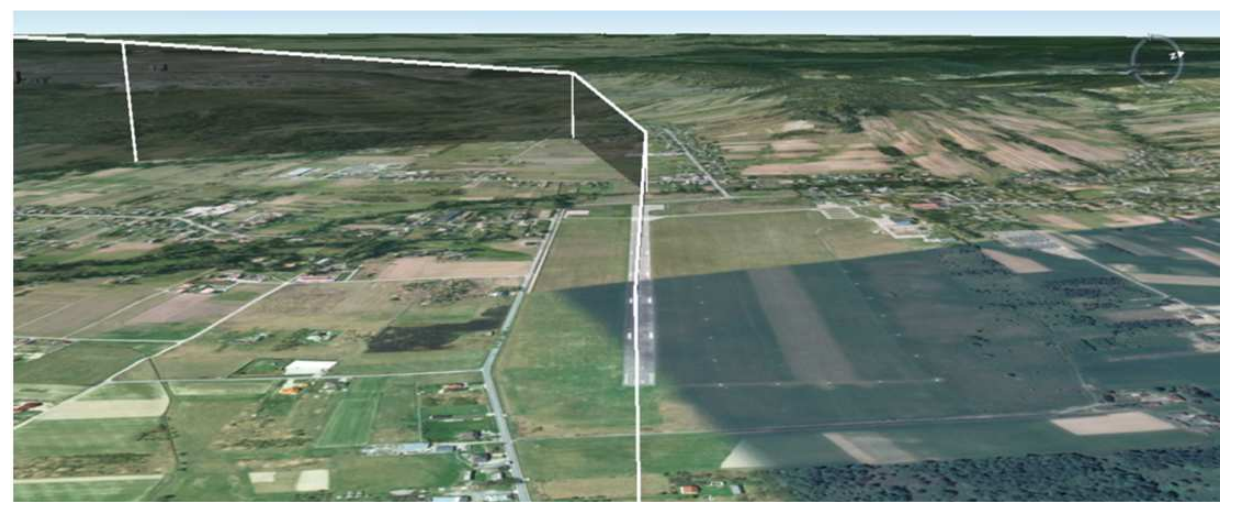

Rys. 7. Płaszczyzna lotu podczas lądowania i startu na lotnisku w Masłowie pod Kielcami

Fig. 7. The flight plane during take-off and landing at the airport in Masłów near Kielce 
Rys. 8. Płaszczyzna lotu i linia prosta łącząca punkty trasowe

Fig. 8. The flight plane and straight line between route points

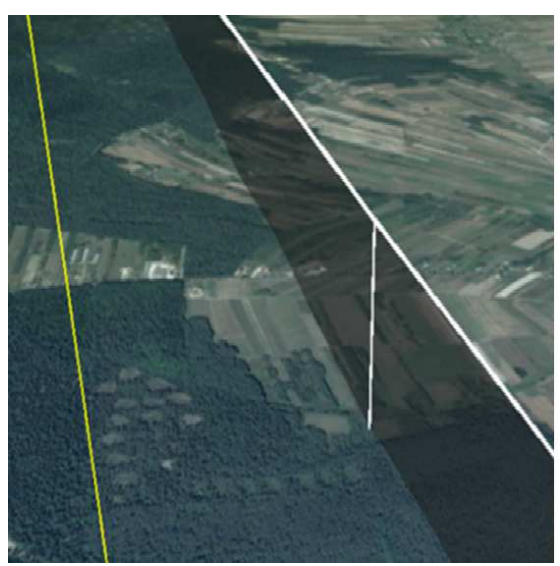

\section{Podsumowanie}

Podsumowując, digitalizacja dokumentacji oraz automatyzacja niektórych czynności na pokładzie może pozytywnie wpłynąć na bezpieczeństwo i komfort podróży. Szczególne znaczenie ma lotnictwo ogólne, gdzie duża część operacji dotyczy załóg jednoosobowych, często stawiających pierwsze kroki w przestworzach. Propozycja własnej aplikacji miała na celu sprawdzenie funkcjonalności tego typu rozwiązań w warunkach lotu rzeczywistego. Biorąc pod uwagę niski nakład finansowy i intelektualny (urządzenie rejestrujące - średniej klasy smartfon, aplikacja stworzona samodzielnie przez studenta nie będącego programistą) jest to bez wątpienia potwierdzenie tezy postawionej przed realizacją

projektu. Warto zatem powoli oswajać się z myślą, iż w niedalekiej przyszłości aplikacje mobilne być może ostatecznie zastąpią dokumentację papierową i zyskają jeszcze szersze grono odbiorców. Nade wszystko należy jednak pamiętać o zasadzie ograniczonego zaufania wobec niecertyfikowanych systemów, które coraz częściej są źródłem informacji mających realny wpływ na bezpieczeństwo lotu.

\section{Literatura}

[1] Hughes D.: EFB Special Edition. Avionics Magazine, June 2009.

[2] SkyBrary: Electronic Flight Bag (dostęp: maj 2016) http://www.skybrary. aero/index.php/Electronic_Flight_Bag.

[3] iPadPilotsNews:http://ipadpilotnews.com/2015/04/whats-best-android-tabletpackage-pilots, (dostęp: kwiecień 2016).

[4] Rozporządzenie Komisji (UE) NR 800/201, Sierpień 2013.

[5] Socata: Instrukcja Użytkowania w Locie samolotu TB-9 Tampico, Wrzesień 1989.

[6] Garmin: Garmin Pilot User's Guide for Android, August 2015.

[7] Jordan L., Greyling P.: Practical Android Projects, Apress, 2011. 
[8] Jeppesen: Jeppesen Mobile FliteDeck User Guide, January 2016.

[9] Robert Goyer: Shttp://www.flyingmag.com/avionics-gear/pilot-supplies/androidaviation-apps- cockpit (dostęp: maj 2016).

\section{DESIGN OF MOBILE APPLICATION FOR GENERAL AVIATION}

\section{S u m m a r y}

This article presents the possibilities of use of mobile applications designed for mobile devices in general aviation. The first part of the article presents the portable electronic devices used on board of modern aircrafts. The second part of the article focuses on the presentation own project realised under the diploma's thesis research. This project has been intended to develop the pilot-aided application during VFR flights The main functions of application are sensor-driven detection of the current phase of flight, recording the selected parameters and automatization selected activities based on the user interaction and data of instrument sensors. The characteristic of the problem, assumptions, and results were discussed. The third section describes the outcome of research conducted in real flight conditions on Socata TB-9 Tampico aircraft at Aviation Training Centre of Rzeszow University of Technology. The substantial parameters of flight, such as position, altitude, ground speed and estimated accuracy of measurement have been registered. The collected data are the base in order to improve algorithms, calibration, and evaluation of required coefficients. Additionally, the flight data has been visualised in Google Earth program by establishing a 3D fight path trajectory. This research can be used for determination of functionality of mobile devices, and to inspire the further research development.

Keywords: mobile application, EFB, general aviation

DOI: $10.7862 / \mathrm{rm} .2017 .19$

Otrzymano/received: 12.10 .2016

Zaakceptowano/accepted: 11.04.2017 